\title{
Identifikasi Salmonella sp. pada Susu Segar di Peternakan Sapi Perah Kecamatan Licin Kabupaten Banyuwangi
}

\author{
Identification of Salmonella sp. on Fresh Milk at Daily Cattle Farm, Licin Sub- \\ districts, Banyuwangi District
}
Rafif Galih Satria ${ }^{*}$, Iwan Sahrial Hamid ${ }^{2}{ }^{\infty}$, Prima Ayu Wibawati ${ }^{3}{ }^{\infty}$,Agnes Theresia

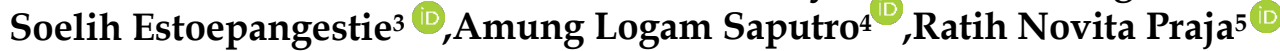

${ }^{1}$ Mahasiswa, ${ }^{2}$ Divisi Ilmu Kedokteran Dasar Veteriner, ${ }^{3}$ Divisi Kesehatan Masyarakat

Veteriner, ${ }^{4}$ Divisi Klinik Veteriner, ${ }^{5}$ Divisi Mikrobiologi Veteriner,

Departemen Ilmu Kedokteran Hewan

Fakultas Kedokteran Hewan, PSDKU Banyuwangi Universitas Airlangga,

Jl. Wijaya Kusuma No. 113, Mojopanggung, Giri, Banyuwangi

*E-mail: rafif.galih.satria-2017@fkh.unair.ac.id

\begin{abstract}
ABSTRAK
Tujuan dari penelitian ini adalah untuk mengetahui tingkat cemaran bakteri Salmonella sp. pada susu segar dari peternakan sapi perah di Kecamatan Licin Kabupaten Banyuwangi. Sampel susu segar di ambil pada April 2021 sebanyak 16 sampel dari KPSP Ijen makmur di Kecamatan Licin Kabupaten Banyuwangi. Sampel diambil sebanyak $25 \mathrm{ml}$ dari masing-masing peternak. Hasil yang di dapat setelah melakukan isolasi dan identifikasi menggunakan media Salmonella Shigella Agar (SSA), dan dilanjutkan uji identifikasi menggunakan TSIA dan Urease didapatkan dari 16 sampel dinyatakan negatif bakteri Salmonella sp. Hal ini dapat terjadi karena para peternak sapi perah di Kecamatan Licin sudah mulai menyadari pentingnya kebersihan kandang dan sanitasi kandang yang baik sehingga tingkat cemaran bakteri Salmonella sp. dapat dicegah.
\end{abstract}

Kata Kunci: sapi perah, susu segar, kebersihan, Salmonella sp.

\begin{abstract}
The purpose of this study was to determine the level of contamination of Salmonella sp. on fresh milk from dairy farms in Licin Sub-districts, Banyuwangi District. Fresh milk samples were taken in April of 2021 as many as 16 samples of KPSP Ijen Makmur in Licin subdistrict of Banyuwangi. Samples were taken as much as $25 \mathrm{ml}$ from each farmer. The results obtained after isolation and identification using Salmonella Shigella Agar (SSA) media, and continued identification tests by using TSIA and Urease were obtained from the 16 samples, and all the samples result were negative. This can happen because the dairy farmers in the district have begun to realize the importance of cage hygiene and good cage sanitation, so that the level of contamination of Salmonella sp. can be prevented.
\end{abstract}

Key words: Dairy cows, fresh milk, hygiene, Salmonella sp.

\section{PENDAHULUAN}

Susu segar merupakan cairan alami yang dikeluarkan dari ambing sapi sehat dan bersih, tanpa mengurangi atau menambahkan dengan bahan lain (BSN, 2011). Produksi susu segar di Provinsi Jawa Timur pada tahun 2018 sebesar 
513.00.00 ton dan pada tahun 2019 sebesar 524.000.00 ton (Badan Pusat Statistik, 2020). Pencemaran bakteri yang terjadi pada susu dapat berasal dari sapi itu sendiri, peralatan yang digunakan pada proses pemerahan dan ruang penyimpanan, debu, air, lalat atau serangga di sekitar kandang ataupun penanganan susu yang salah dari peternak (Roumbaut, 2005).

Syarat mutu susu segar adalah memiliki batas maksimum cemaran bakteri (Total Plate Count/TPC) $\left(1 \times 10^{6}\right.$ CFU/ml), Coliform (20/ml), Most Probable Number (MPN) Escherichia coli $<3 / \mathrm{ml}$. Staphylococcus aureus $\left(1 \times 10^{2} / \mathrm{ml}\right)$, serta negatif atau tidak adanya bakteri Salmonella, E. coli (patogenik), dan Streptococcus Group B (BSN, 2009).

Salmonella $s p$. merupakan salah satu bakteri patogen yang menyebabkan penyakit foodborne disease yaitu penyakit yang disebabkan karena mengkonsumsi makanan atau minuman yang telah tercemar (Arifin, 2015). Pencemaran yang terjadi pada susu dapat mengakibatkan penurunan kualitas susu dan hal ini ditandai dengan perubahan warna, aroma, konsistensi dan tampilan susu yang tidak sewajarnya (Handayani dan Maya, 2010).

Banyuwangi adalah kabupaten terluas di Jawa Timur sekaligus menjadi yang terluas di Pulau Jawa, dengan luas wilayah mencapai $5.782,50 \mathrm{~km}^{2}$ dan terdiri dari 25 Kecamatan. Jumlah sapi perah di Kabupaten Banyuwangi pada tahun 2018 sebanyak 698 ekor dengan produksi susu segar sebanyak $1.397 .635 \mathrm{~kg}$ (Dinas Pertanian Kabupaten Banyuwangi, 2018).

Kecamatan Licin merupakan salah satu kecamatan di Banyuwangi dengan komoditas utama penghasil susu segar dari para peternak sapi perah yang akan di distribusikan ke salah satu industri pengolahan susu terbesar di Indonesia. Penelitian ini bertujuan untuk mengetahui tingkat cemaran bakteri Salmonella sp. pada peternakan sapi perah di Kecamatan Licin Kabupaten Banyuwangi.

\section{BAHAN DAN METODE}

Penelitian ini bersifat deskriptif dengan mengetahui tingkat kontaminasi bakteri Salmonella sp. Sampel diambil menggunakan teknik non-probability sampling, teknik saturation sampling yaitu sampel tidak dipilih dengan acak. Susu sapi segar yang diuji menggunakan media Salmonella Shigella Agar (SSA). Penelitian dilakukan pada bulan April 2021. Sampel yang digunakan sebanyak 16 sampel dimana masing- masing sampel di ambil $25 \mathrm{ml}$ untuk dilakukan pengujian. Sampel diambil melalui Koperasi Peternak Sapi Perah (KPSP) Ijen Makmur yang didapatkan dari seluruh anggota koperasi yang menyetor. Sampel yang di dapat dilakukan isolasi menggunakan media Salmonella Shigella Agar (SSA) kemudian dilanjutkan dengan uji identifikasi menggunakan media Triple Sugar Iron Agar (TSIA) dan Urease.

\section{HASIL DAN PEMBAHASAN}

Hasil penelitian menggunakan media Salmonella Shigella Agar (SSA), koloni yang terbentuk berwarna merah muda dan bergerombol membentuk merah muda pada media SSA seperti Gambar 1. Bakteri yang dapat menimbulkan warna merah muda pada media SSA memiliki daya fermentasi laktosa yang lambat. Selanjutnya dilakukan tahap identifikasi dengan menggunakan media Triple Sugar Iron Agar (TSIA) dan didapat hasil seperti Gambar 2, 
serta dilakukan uji biokimia menggunakan Uji urease. Uji TSIA untuk mengkonfirmasi kemampuan kuman memfermentasikan glukosa, laktosa dan sukrosa.
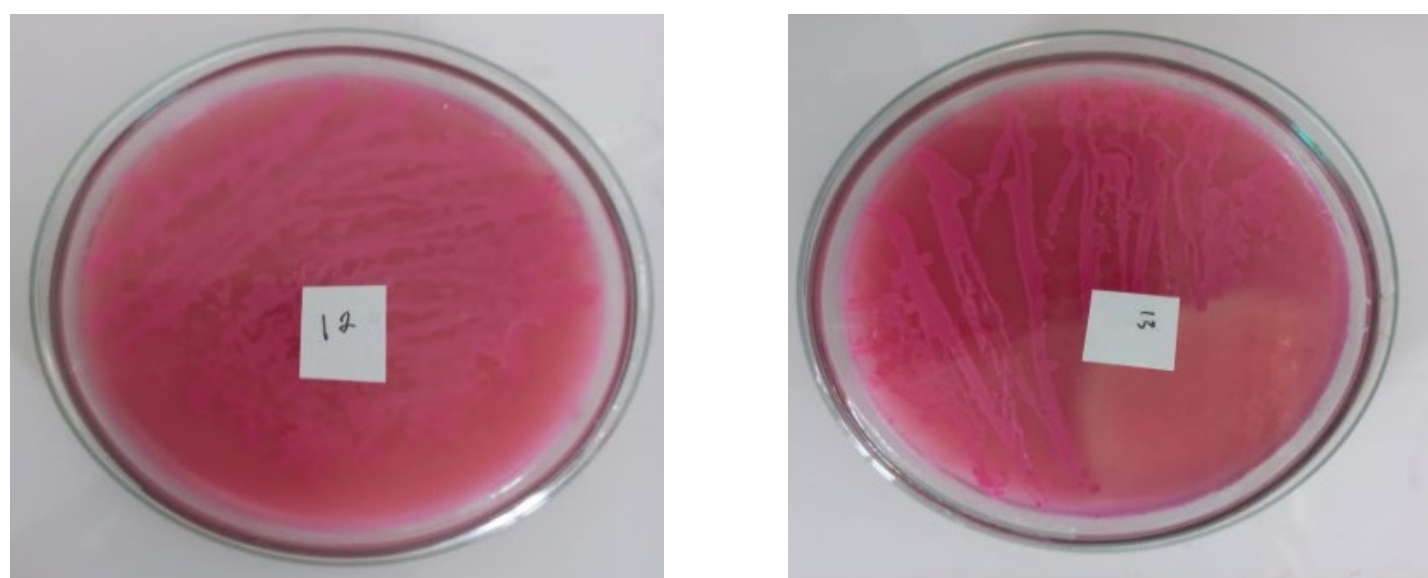

\section{Gambar 1. Hasil Isolasi Pada Media SSA, Koloni Bakteri Berwarna Merah Muda, Negatif Koloni Salmonella sp.}

Uji urease dilaksanakan menggunakan media urea agar dan hasil yang didapat menunjukkan bahwa 16 sampel negatif bakteri Salmonella sp. yang ditanndai dengan tidak berubahnya media urea agar di dalam tabung reaksi seperti

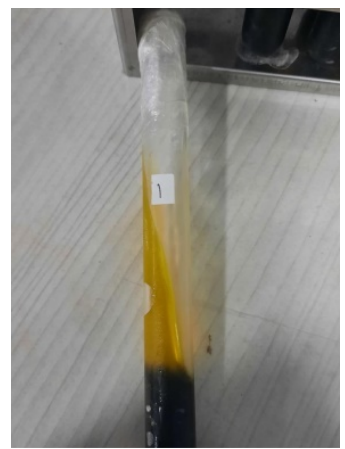

\section{Gambar 2. Hasil Uji TSI-A Negatif Salmonella sp.}

Bakteri Salmonella sp. tidak ditemukan pada sampel susu segar dipegaruhi oleh beberapa faktor diantaranya, manajemen kandang yang cukup baik, proses pemerahan yang higenis karena memperhatikan kebersihan sebelum melakukan pemerahan, sanitasi kandang yang bersih dan baik, serta
Gambar 3. Uji urease digunakan untuk mengidentifikasi bakteri yang menghasilkan enzim urease sehingga bakteri tersebut dapat menguraikan urea dengan ditandai perubahan warna menjadi merah keunguan.

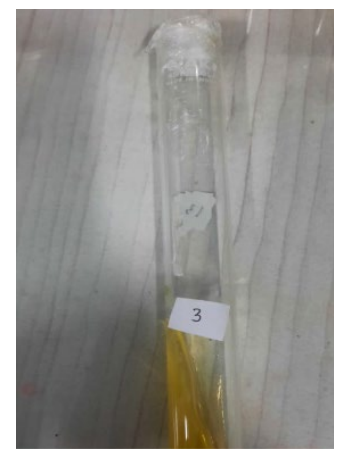

\section{Gambar 3. Hasil Uji Urease Negatif Salmonella sp.}

peternak atau pemerah yang memperhatikan kualitas kebersihan di area sekitar kandang. Sanitasi meliputi kebersihan kandangan dan lingkungan kandang untuk menjaga kesehatan manusia dan hewan ternaknya (Yuliani, 2016). Produk hewan yang berasal dari peternakan yang kurang memperhatikan 
kebersihan rentan dan beresiko lebih besar terkontaminasi Salmonella sp.. Pekerja pemerah susu atau peternak sapi perah adalah salah satu faktor perantara yang dapat mengkontaminasi susu segar, salah satu hal yang dapat mengakibatkan kontaminasi tersebut ialah para pekerja dan peternak tidak melakukan desinfeksi atau tidak mencuci tangan dengan sabun terlebih dahulu sebelum melakukan kegiatan di sekitar sapi. Sanitasi dan manajemen kandang meliputi kebersihan ternak, kebersihan alat pemerahan, kebersihan lingkungan sekitar, kebersihan alat pemerahan, dan kebersihan sumber air serta penanganan susu paska pemerahan (Wicaksono, 2017). Cemaran bakteri Salmonella sp. dan tingkat kualitas susu dapat dipengaruhi dari kebersihan tangan karena pada saat proses pemerahan tangan bagian telapak yang mengandung banyak bakteri dan dapat mengkontaminasi susu jika sebelum proses pemerahan tangan dalam keadaan kotor dan belum dibersihkan atau desinfeksi (Wijiastutik, 2012). Pencemaran bakteri pada susu dapat menurunkan kualitas dan keamanan susu sebagai bahan makanan yang ditandai dengan aroma, rasa, konsistensi, dan penampakan (Chotiah, 2020).

\section{KESIMPULAN}

Kesimpulan yang dapat di ambil berdasarkan penelitian ini adalah susu segar yang di ambil dari KPSP Ijen Makmur Kecamatan Licin Kabupaten Banyuwangi yang diuji tidak mengandung cemaran bakteri Salmonella sp. dan sesuai dengan batas maksimum yaitu negative/ 25ml yang ditetapkan SNI 7388:2009.
Penulis mengucapkan terimakasih kepada seluruh pihak yang turut mendukung penulis dalam menyusun penelitian ini baik secara langsung maupun tidak langsung. Terutama untuk dosen pembimbing dan seluruh civitas akademika Universitas Airlangga PSDKU Banyuwangi serta teman-teman penulis.

\section{DAFTAR PUSTAKA}

Arifin, I.M. 2015. Deteksi Salmonella sp. Pada Daging Sapi di Pasar Tradisional dan Pasar Modern di Kota Makassar. Skripsi. Program Studi Kedokteran Hewan, Fakultas Kedokteran, Universitas Hasanuddin.Makassar.

Badan Pusat Statistik. 2020. Diakses tanggal 19 Februari 2021, https://www.bps.go.id/indicator /24/493/1/produksi-susu-segarmenurut-provinsi.html.

BSN (Badan Standardisasi Nasional). 2009. Standar Nasional Indonesia (SNI) No. 7388:2009 tentang Batas maksimum Cemaran Mikroba dalam Pangan. Jakarta.

BSN (Badan Standardisasi Nasional). 2011. Standar Nasional Indonesia (SNI) No. 3141-01:2011 tentang Susu Segar. Jakarta.

Chotiah, S. 2020. Beberapa bakteri patogen yang mungkin dapat ditemukan pada susu sapi dan pencegahannya. Semiloka Nasional Prospek Industri Sapi Perah menuju Perdangan Bebas

Dinas Pertanian Kabupaten Banyuwangi. 2018. Diakses tanggal 19 Februari 2021 ,

https://dinaspertanian.banyuwan 
gikab.go.id/page/view/datatahunan-bidang- peternakan.

Handayani, K. S., dan P. Maya. 2010. Kesehatan ambing dan higien pemerahan di peternakan sapi perah desa pasir buncir kecamatan caringin. Jurnal Penyuluhan Peternakan; 5: 1 .

Roumbaut, R. 2005. Dairy Microbiology and Starter Cultures. Laboratory of Food Technology and Engineering. Gent University. Belgium.

Wicaksono, A., dan M. Sudarwanto. 2017. Peningkatan kualitas susu peternakan rakyat di Boyolali melalui program penyuluhan dan pendampingan peternak sapi perah. Agrokreatif Jurnal Ilmiah Pengabdian kepada Masyarakat, 2(2), 55-60.

Wijiastutik, D. 2012. Hubungan Higiene dan Sanitasi Pemerahan Susu Sapi dengan Total Plate Count pada Susu Sapi di Peternakan Sapi Perah Manggis Kabupaten Boyolali. Jurnal Kesehatan Masyarakat Volume 1 Nomer 2 Tahun 2012. Universitas Diponegoro.

Yuliani, N. S. 2016. Pengendalian Thelaziasis pada Ternak Sapi dengan Menggunakan Rebusan Daun Sirih di Desa Oefafi.. Jurnal Pengabdian Masyarakat Peternakan, 1(2). 